\title{
Retrofit assessment of masonry buildings through simplified structural analysis
}

\author{
Mariateresa Guadagnuolo, Marianna Aurilio, Giuseppe Faella \\ Department of Architecture and Industrial Design, Università degli Studi della Campania Luigi Vanvitelli, S.Lorenzo ad \\ Septimum Abbey, Aversa (CE) Italy. \\ mariateresa.guadagnuolo@unicampania.it, bttp://orcid.org/0000-0002-8273-4846 \\ marianna.aurilio@unicampania.it, bttp://orcid.org/0000-0002-8234-4127 \\ giuseppe.faella@unicampania.it,bttp:/ /orcid.org/0000-0002-1941-9675
}

\begin{abstract}
The current seismic prevention strategy is based on a unitary approach aimed at a risk mitigation, also at territorial level. The Italian guidelines for the assessment and mitigation of seismic risk of cultural heritage provides indications for the seismic analysis of protected cultural heritage, with the aim of specifying a path of knowledge, assessing the level of safety and planning possible improvements. The Italian building heritage is very vast and heterogeneous and was devastated by earthquakes due to its high vulnerability; therefore, the seismic risk mitigation also requires the availability of simple and handy analysis tools. The aim of this paper is the illustration of an easy, although approximate, procedure for the evaluation of the seismic safety index and the optimization of strengthening interventions. The procedure is applied to buildings located in the province of Caserta. The analyses are performed with reference to two types of buildings that are particularly recurrent and representative of the building heritage of this area and placed in areas with different seismic hazard.
\end{abstract}

KEYWORDS. Seismic risk mitigation; Masonry buildings; Strengthening optimization; Province of Caserta.

\section{OPEN $\bigcirc$ ACCESS}

Citation: Guadagnuolo, M., Aurilio, M., Faella, G, Retrofit assessment of masonry buildings through simplified structural analysis, Frattura ed Integrità Strutturale, 51 (2020) 398-409.

Received: 15.06 .2019

Accepted: 01.12.2019

Published: 01.01.2020

Copyright: (C) 2020 This is an open access article under the terms of the CC-BY 4.0, which permits unrestricted use, distribution, and reproduction in any medium, provided the original author and source are credited.

\section{INTRODUCTION}

1 he Italian building heritage consists of masonry constructions, a wide part of which is located in historic centres, what deserve particular attention as bearers of inestimable values due to their existence over time, which makes it a rich historical, artistic, and cultural environment.

The value of these constructions lies in the inestimable meaning that emerges from them, indissolubly linked to the history and evolution of the Italian country $[1,2]$. Most of these buildings belong to periods when there were no rules to observe in their construction, and many were built using rules different from those used today and without seismic criteria [3]. Furthermore, existing buildings are often characterized by problems due to degradation and longevity [4-6]. The desire 
to preserve these buildings is linked to the need to transfer the Italian heritage, and therefore its history, to posterity. Moreover, this issue is as important as extremely complicated, above all due to the presence of an excessive degradation and the low seismic capacity that characterizes these structures $[7,8]$.

Due to the recent code developments and the increasing attention given to the seismic safety of existing structures, especially after the last Italian earthquakes, the analysis of existing built heritage and the improvement of its seismic performance have become a fundamental issue $[9,10]$. The current seismic prevention strategy is based on a unitary approach that primarily envisages a risk mitigation through the seismic classification of the territory and the retrofitting and strengthening of existing buildings; and any contrast between conservation, interventions, and structural safety must be avoided [11-13].

The Italian guidelines for the assessment and mitigation of seismic risk of cultural heritage (Directive 2011) [14] provide specific indications for the assessment and reduction of seismic risk of protected cultural heritage. It specifies a path of knowledge, assessment of safety level against seismic loads and planning of possible interventions, conceptually similar to those provided for unprotected buildings, but suitably adapted to the needs and peculiarities of cultural heritage [15].

The Italian building heritage is characterized by high complexity and heterogeneity, both from an architectural and structural point of view. A significant number of old stone and masonry buildings do not comply with any provisions of current codes and have low seismic capacity and in general sophisticated analyses are necessary to assess their vulnerability $[16,17]$. For all these reasons, is therefore essential to have lean procedures that allow the evaluation of the seismic risk assessment of existing buildings to establish priorities in a long-term prevention policy. In addition, it is important to define a methodology to obtain comparable results to plan future activities of analysis, evaluation and risk management.

Due to the size and the number of buildings involved, the currently available methodologies for assessing the seismic vulnerability of urban areas usually require the treatment of an enormous volume of data associated with inspection and investigation work. For this reason, the use of simplified procedures is becoming more popular [18]. The vulnerability index method uses the information gathered about the main building parameters (plan, height, structural and nonstructural elements, type and quality of materials), and is one of several general methods for seismic risk analysis. In [19] an easily manageable procedure is presented, adaptable to different buildings, but at the same time able to determine the current state of the structures and their structural deficiencies.

The current conditions obviously lead to analyses aimed at improving the seismic performance of as much heritage as possible, avoiding the types of strengthening selected in the past that were not always suitable with respect to both the static condition and characteristics of the buildings and the respect of economic thresholds [20]. In fact, many strengthening adopted in the past have proved ineffective to withstand intense seismic actions [21].

In the present paper, a seismic analysis is performed by applying a simplified method for evaluating the safety index, before and after retrofitting interventions. Specifically, an approximate procedure is presented to optimize the type and quantity of the necessary local interventions. The analyses are performed with reference to two types of buildings that are particularly recurrent and representative of the built heritage in the province of Caserta and located into areas with different seismic hazard. The aim of the paper is to provide a first step to reduce the seismic risk of the analysed buildings, through very simple analyses of site and existing buildings.

\section{CASES STUDY}

1 he present study analyses two residential buildings, representative of the great majority of the existing buildings in the historic centers of the province of Caserta but located into two areas with different characteristics.

The choice of these two buildings is representative of the great variation that exists in cities even belonging to the same province.

Although they are both noble buildings, belonging to two different periods and to two distinct cities is also pointed out in the constructive differences starting from the types of material used and from the development of the construction.

These buildings were built in the XV century and in a period between 1800 and the beginnings of 1900 . They are mainly simple or massive stones masonry buildings and develop around a court or a central courtyard, generally built for at least two or three stories. The buildings are isolated or enclosed in urban agglomeration, and usually have timber or steel floors and no thrusting roof.

\section{"Palazio Petrucci-Novelli"}

The building was realized around the XIV century and it is a typical example of the construction typology of the area (Fig. 1). It is located in the historic center of Carinola (province of Caserta), a town that presents a medium-low seismic hazard. 
The building has a compact shape and an irregular morphology both in plan and in elevation. It is on two levels around a central courtyard, where an external staircase connects the ground floor to the loggia, as shown in Fig. 2 , Fig. 3 and in Fig. 4. The masonry consists of simple regular stone blocks; the walls are $60 \mathrm{~cm}$ thick. The floors present a large variation: cross vaults, barrel vaults and flat slab are present, while the roof is made by timber trusses.
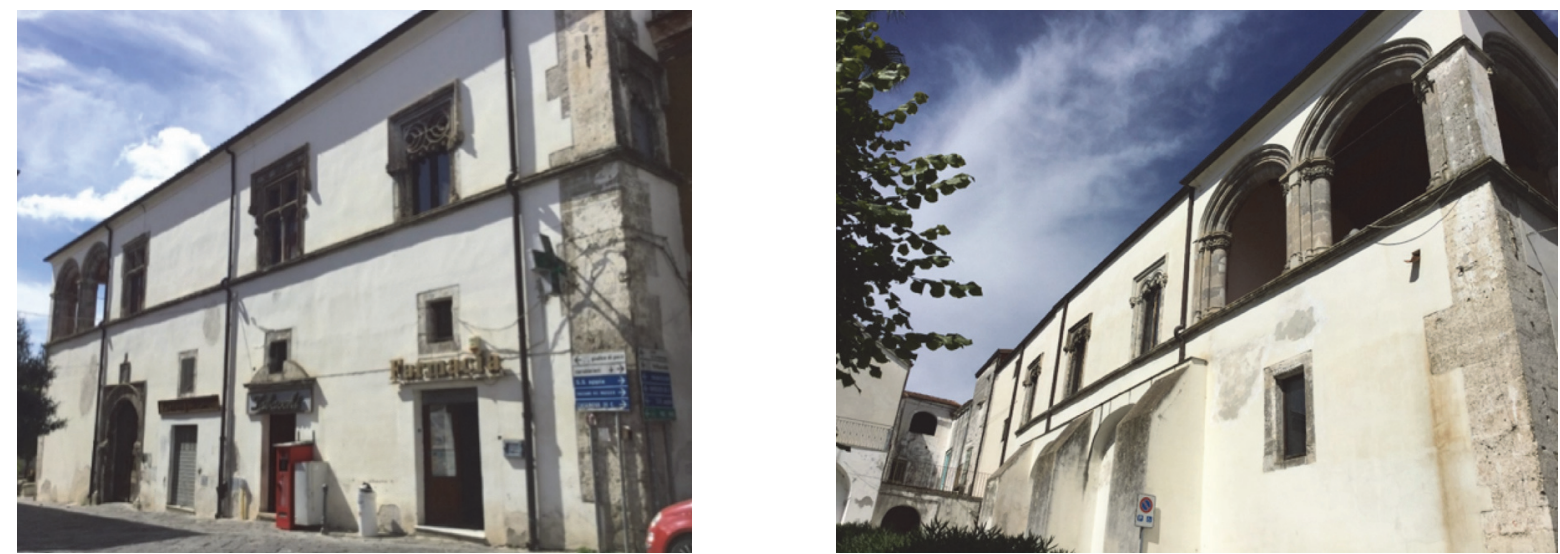

Figure 1: External front views.

(1)
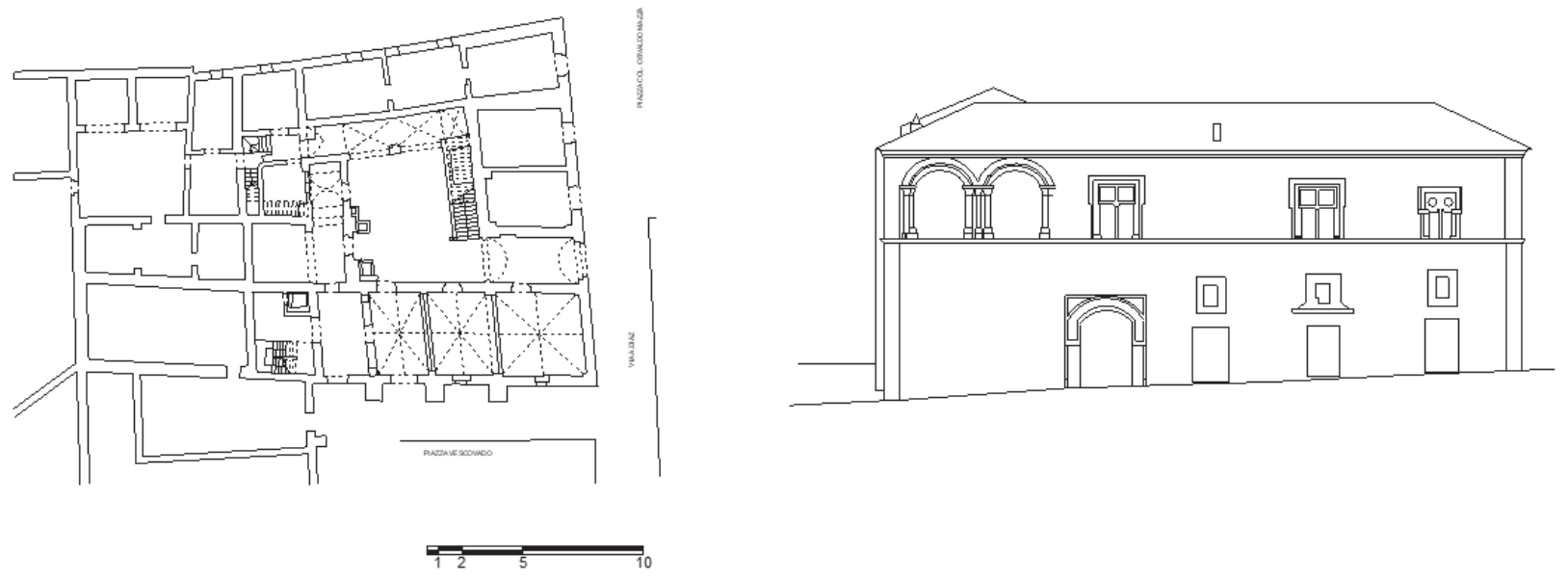

Figure 2: Ground floor plan.

Figure 3: Elevation.
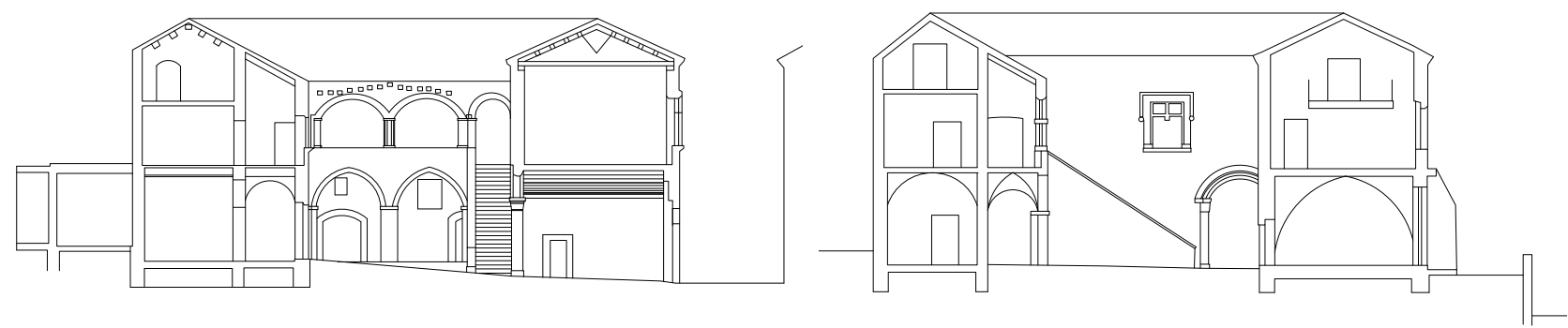

Figure 4: Sections drawings.

"Palazzo Ducale"

The building (Fig. 5) is located in the historic center of Piedimonte Matese, in the province of Caserta. It is a prototype of the construction typology of the Middle Volturno's area, next to the Apennines; therefore, a district with high seismic hazard. The palace, built in the XVI century, consists of a massive stone masonry mixed to fieldstone and brick blocks 
with a thickness of about $80 \mathrm{~cm}$. The building has four levels, arranged around a central courtyard and has a compact shape and an irregular morphology in both in plan and in elevation, as shown in Fig. 6, Fig. 7 and in Fig. 8
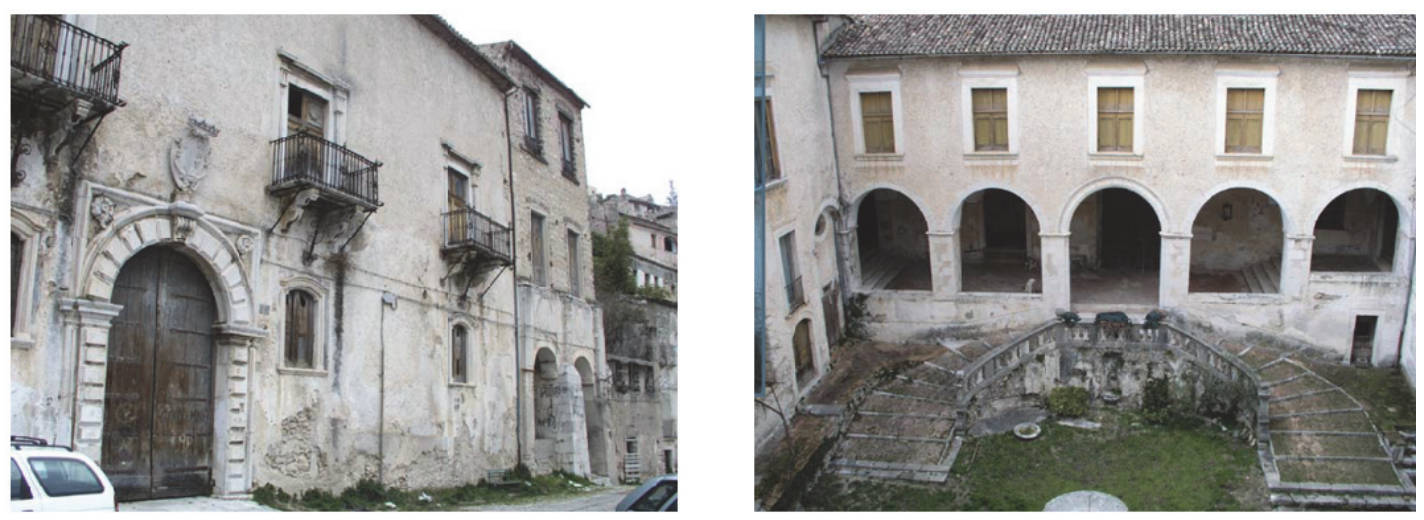

Figure 5: External front views.

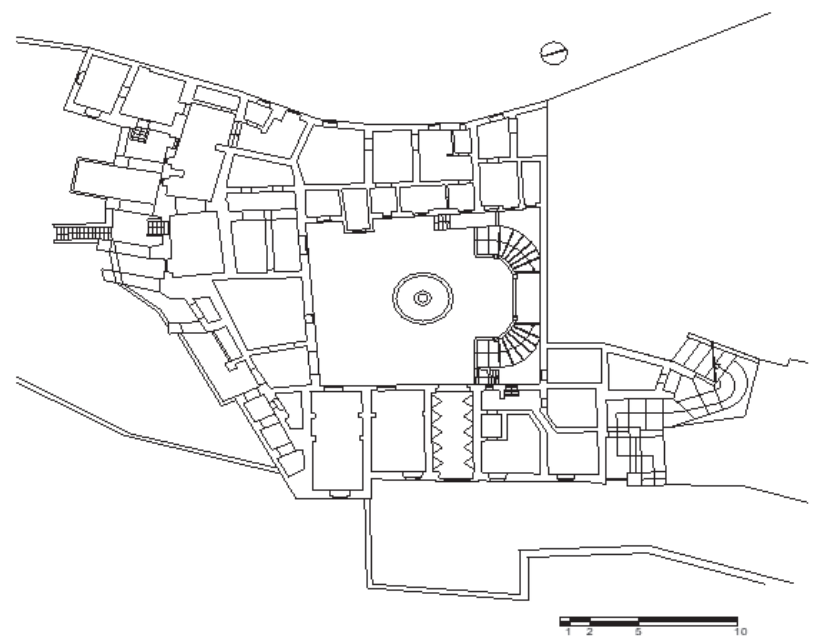

Figure 6: Ground floor plan.
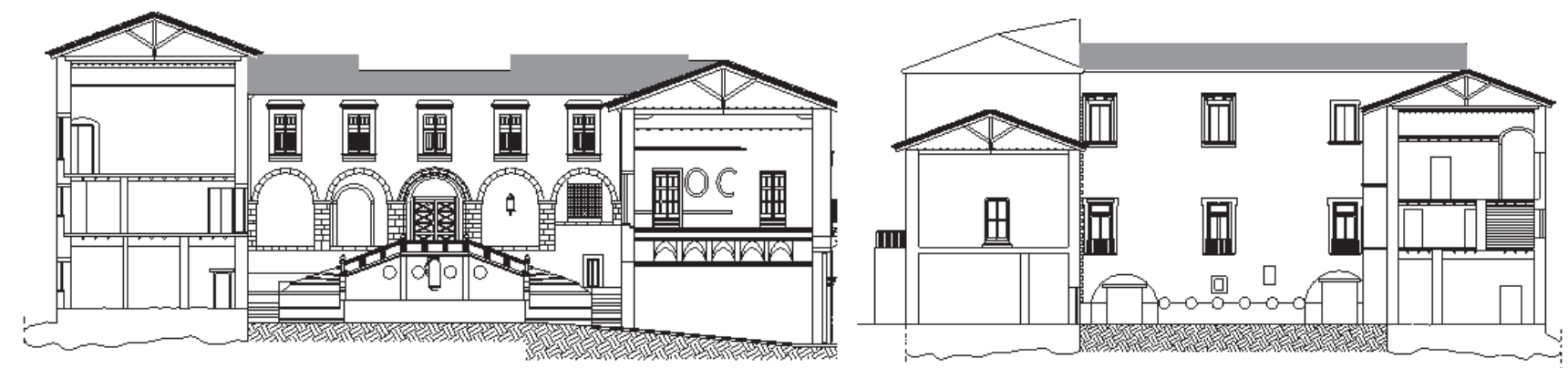

Figure 8: Sections drawings

\section{Results Obtained Using the Italian Guidelines for the Assessment and Mitigation of SEISMiC Risk of Cultural Heritage}

$\mathrm{T}$

he Italian National "Guidelines for evaluation and mitigation of seismic risk of cultural heritage" [14] identify different simplified mechanical models aimed at evaluating the seismic risk of most common masonry buildings types such as buildings, palaces and other structures with bearing walls and horizontal diaphragms [22], churches 
and other structures with large halls [23,24], without intermediate diaphragms [25], towers, bell towers, and other tall and slender structures [26].They are strongly linked to the Italian Building Code [27], recently updated with a new version [28], which contains all the parameters necessary to perform a reliable seismic analysis.

To evaluate the seismic safety, three different levels of increasing completeness have been identified, of which the LV1 level concerns the assessment of seismic safety index on a territorial scale, also to establish the priority degree of interventions; this method is based on a limited number of geometric and mechanical parameters or visual tests, being linked only to a simplified type of evaluation; as will be better clarified by the following procedure (Eqns. 1-9) [14].

Same papers compare simplified approaches with more sophisticated procedures [29, 30]; however, retrofitting and strengthening of existing buildings have to be designed through refined non linear analyses [31].

If the seismic safety index estimated using the procedure is greater than the unit, the structure is able to withstand the seismic forces required by the seismic code, on the contrary no. This is useful for highlighting critical situations and establishing a priority for the interventions [27, 28].

The seismic safety index $I_{S P}$ is estimated by the ratio between the return period of the seismic action $T_{S L V}$ of the earthquake which gets the building to reach the ultimate limit state and the expected return period of the earthquake on the site $T_{R, S L V}$.

$$
I_{S P,(S L V)}=\frac{T_{S L V}}{T_{R, S L V}}
$$

and

$$
T_{R, S L V}=-\frac{V_{R}}{\ln \left(1-P_{V R}\right)}
$$

where:

$V_{\mathrm{R}}$ is the reference period;

$P_{V R}$ is probability of exceedance in the reference period.

In the same way, an acceleration safety index $\mathrm{I}_{\mathrm{SA}}$ is computed as the ratio between the peak ground acceleration of the earthquake which gets the building to the limit state of activation $a_{S L V}$ and the peak ground acceleration of the design earthquake $a_{g, S L V}$, related to the site:

$$
I_{S A}=\frac{a_{S L V}}{a_{g, S L V}}
$$

$a_{g, S L V}$ is the design ground acceleration, corresponding to the assigned return period of the earthquake, related to the subsoil;

$a_{S L V}$ is the ground acceleration leading to the achievement of the structure ultimate limit state (SLV), computed as a function of the fundamental period of vibration T1 of the structure [30].

$$
\begin{aligned}
& a_{S L V}=\frac{s_{e, S L V}\left(T_{1}\right)}{S \cdot F_{0}} T_{B} \leq T_{1} \leq T_{C} \\
& a_{S L V}=\frac{s_{e, S L V}\left(T_{1}\right)}{S \cdot F_{0}} \cdot \frac{T_{1}}{T_{C}} \quad T_{C} \leq T_{1} \leq T_{D}
\end{aligned}
$$

where the ordinate value of the elastic response spectrum $s_{e, S L V}$ is: 


$$
s_{e, S L V}=\frac{q \cdot F_{S L V}}{e^{*} \cdot M}
$$

$\mathrm{q}$ is the behavior factor, $F_{S L V}$ is the lower building shear strength, $e^{*}$ is the mass fraction participant to the first mode of vibration and $\mathrm{M}$ is the total seismic mass.

The procedure used, in the case in which the mode of collapse is not defined with precision, allows us to assume a triangular modal shape, corresponding to the following values for the mass fraction participant on the first mode and for the coefficient that defines the force at the i-th plane:

$$
e^{*}=0,75+0,25 N^{-0,75}
$$

The capacity models assumed for the analyzed structures are subject to shear failure at each level [32, 33]. The shear strength of the building is the lowest among those evaluated in two main direction.

$$
F_{S L V, x i}=\frac{\mu_{x i} \xi_{x i} \zeta_{x i} A_{x i} \tau_{d i}}{\beta_{x i} \kappa_{i}} \quad F_{S L V, y i}=\frac{\mu_{y i} \xi_{y i} \zeta_{y i} A_{y i} \tau_{d i}}{\beta_{y i} \kappa_{i}}
$$

$A_{x i}$ and $A_{y i}$ are shear resistant areas of the $\mathrm{i}$-th floor walls according respectively to $\mathrm{x}$ and $\mathrm{y}$ direction;

$\beta_{x i}$ and $\beta_{y i}$ are plan irregularity factors related to the i-th floor;

$\mu_{x i}$ and $\mu_{y i}$ are coefficients considering, at the i-th floor, the stiffness and strength homogeneity of masonry walls according respectively to $\mathrm{x}$ and $\mathrm{y}$ direction.

The failure mechanisms considered are that expected in masonry walls (Fig. 9): collapse of piers due to shear or bending forces, also depending on the strength of the spandrel beams [14, 34]. In masonry piers, the coefficients of failure mechanisms $\xi_{x i}$ and $\xi_{y i}$ assume value of 1 in the case of shear failure and 0.8 in the case of eccentric axial force failure; the coefficients related to the spandrel beams resistance $\zeta_{\mathrm{xi}}$ and $\zeta_{\mathrm{yi}}$ assume values 1.0 in the case of strong spandrel beams and 0.8 and in the case of weak spandrel beams.

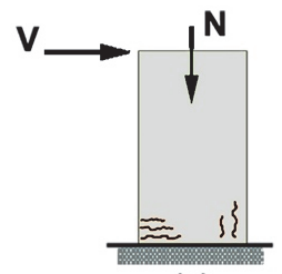

(a)

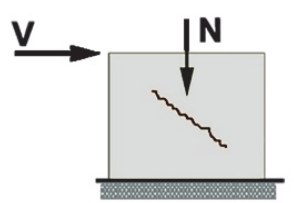

(b)

Figure 9: In-plane failure modes of masonry piers subjected to eccentric axial force: (a) flexural, (b) shear diagonal cracking.

The coefficients $\zeta_{x i}$ and $\zeta_{y i}$ are related to the spandrel resistance of the $\mathrm{i}$-th floor masonry walls: their values are 1.0 in case of strong spandrel and 0.8 and in case of weak spandrel, while $\tau_{d i}$ is the design value of the masonry piers shear strength at the i-th floor, defined as:

$$
\tau_{d i}=\sqrt{1+\frac{\sigma_{0 i}}{1.5 \cdot \tau_{0 i}}}
$$

where $\sigma_{0 i}$ is the design shear strength of masonry and $\sigma_{0 i}$ is the average normal stress on walls at the i-th floor. In the preliminary analysis the structure is examined in its actual state before the intervention, identifying the deficiencies and the seismic level at which the limit state of the collapse mechanism activation is achieved. The reference peak ground accelerations are computed using the following seismic parameters: 


\begin{tabular}{lccccccc}
\hline & Latitude & Longitude & $\mathrm{V}_{\mathrm{N}}$ & Use Class & $\mathrm{C}_{\mathrm{U}}$ & Site Class & $\mathrm{ag}_{\mathrm{g}}$ \\
Palazzo Petrucci Novelli & 41.188625 & 13.976842 & 50 years & II & 1 & A & $0.098 \mathrm{~g}$ \\
Palazzo Ducale & 41.365277 & 14.383055 & 50 years & II & 1 & A & $0.249 \mathrm{~g}$ \\
\hline
\end{tabular}

Table 1: Values of seismic parameters.

\section{"Palazzo Petrucci Novelli"}

The structure is composed by three different levels; the first one has steel floors and several vaults, the second one has steel and timber floors, while the roof consists of timber structures. The corresponding loads at each level are summarized in the Tab. 2.

\begin{tabular}{cccc}
\hline Level & Dead loads: $G_{\mathrm{k}}$ & Live loads: $Q_{\mathrm{k}}$ & $\begin{array}{c}\text { Masonry } \\
\text { Weight }\end{array}$ \\
$1^{\circ}$ & $12 \mathrm{kN} / \mathrm{m}^{2}$ & $2 \mathrm{kN} / \mathrm{m}^{2}$ & $16 \mathrm{kN} / \mathrm{m}^{3}$ \\
$2^{\circ}$ & $6 \mathrm{kN} / \mathrm{m}^{2}$ & $2 \mathrm{kN} / \mathrm{m}^{2}$ & $16 \mathrm{kN} / \mathrm{m}^{3}$ \\
$3^{\circ}$ & $1.7 \mathrm{kN} / \mathrm{m}^{2}$ & $2 \mathrm{kN} / \mathrm{m}^{2}$ & $16 \mathrm{kN} / \mathrm{m}^{3}$ \\
\hline
\end{tabular}

Table 2: Values of loads and masonry parameters.

The confidence factor $\mathrm{F}_{\mathrm{C}}$ assumed is equal to 1.35 (corresponding to complete survey of the building geometry but limited knowledge of material mechanical properties). In this case the shear strength is equal to $0.028 \mathrm{MPa}$ while the failure coefficients related to the type of failure expected in masonry piers $\left(\mathrm{Cp}=\xi_{i}\right)$ and the resistance of spandrel beams $\left(\mathrm{Cs}=\zeta_{i}\right)$ are assumed equal to 0.8 .

According to the procedure provided in [14] for "Building Structures", a minimum safety index IS (minimum between $\mathrm{I}_{\mathrm{SP}}$ and $\mathrm{I}_{\mathrm{SA}}$ ) equal to 0.45 has been computed. Therefore, the building is not capable to withstand the design earthquake.

\section{"Palazzo Ducale"}

The confidence factor $\mathrm{F}_{\mathrm{C}}$ is equal to 1.35 ; the shear strength is equal to $0.028 \mathrm{MPa}$ and $\mathrm{Cp}$ and $\mathrm{Cs}$ have been also assumed equal to 0.8 in this case.

Based on the above data, the smaller safety index is equal to $\mathrm{I}_{\mathrm{S}}=0.25$, indicating that the structure is unable to withstand the seismic forces provided by the seismic code.

\begin{tabular}{cccc} 
Level & Dead loads: $G_{\mathrm{k}}$ & Live loads: $\mathrm{Q}_{\mathrm{k}}$ & $\begin{array}{c}\text { Masonry } \\
\text { Weight }\end{array}$ \\
$1^{\circ}-2^{\circ}-3^{\circ}$ & $5.4 \mathrm{kN} / \mathrm{m}^{2}$ & $2 \mathrm{kN} / \mathrm{m}^{2}$ & $19 \mathrm{kN} / \mathrm{m}^{3}$ \\
$4^{\circ}$ & $0.5 \mathrm{kN} / \mathrm{m}^{2}$ & $2 \mathrm{kN} / \mathrm{m}^{2}$ & $19 \mathrm{kN} / \mathrm{m}^{3}$ \\
\hline
\end{tabular}

Table 3: Values of loads and masonry parameters

\section{SELECTION AND OPTIMIZATION OF INTERVENTIONS}

7 he procedure aims at locally strengthening the buildings and increasing their seismic safety index. The choice of retrofit interventions must be based on a motivated strategy aimed at involving only selected building elements to be reinforced to improve structural performance.

Through the simplified procedure provided by the Italian Guidelines for the evaluation and mitigation of seismic risk of cultural heritage and following the examples of this paper it is possible to identify the weakest level of a generic building 
by a few simple steps, to optimize the interventions, focusing them on the story where they need: in fact, starting from the current conditions of the building, it is possible to hypothesize interventions only on some structural elements (piers or spandrel beams) of a generic story. In fact, there are interventions that affect the resistance of single piers and/or spandrels and those that modify their failure mode. This last aspect can be taken into account in the numerical model by increasing the failure coefficient $\mathrm{Cp}$ or Cs relative only to the involved piers or spandrels. Then, the structural analysis is performed again to recalculate the safety indices $\mathrm{I}_{\mathrm{SP}}$ and $\mathrm{I}_{\mathrm{SA}}$. The procedure is then repeated several times until the safety indices reach an acceptable value or until it is possible to increase the strength of the structural elements or change their collapse modes.

\section{"Palazzo Petrucci Novelli"}

In this case, the Fig. 10 shows the increment curve of the minimum safety index $\mathrm{I}_{\mathrm{S}}$ of the building, obtained through a combination of gradual increases in the shear strength of masonry piers (shown in the figure through an increase coefficient If), of the failure coefficients of piers and the resistance of spandrel beams (Cp, Cs) at different floors of the building. It is considered that the If coefficient could not be higher than 1.50 (which corresponds to a maximum increase of $50 \%$ in resistance of the masonry piers); the failure coefficients $\mathrm{Cp}$ and Cs cannot, on the other hand, obviously be greater than 1.0. With the aforementioned procedure, it was possible to increase the minimum safety index Is from the initial value of 0.45 up to 0.73 .

The procedure starts from the weak level. In this case the ratio between the shear strength of each level and the shear strength of the entire construction highlights the distribution percentage of this force, immediately identifying the weakest level as shown in Fig. 10.

The three black points represent the values of the safety index achieved by maximizing the shear strength of piers (If $=$ $1.5)$ and the failure coefficients $(\mathrm{Cp}=\mathrm{Cs}=1)$, one floor at a time.

The gradually increasing curve of the seismic safety index and the points of maximum increase differ from each other in the different design choices. The points of maximum increase correspond to widespread interventions on the entire construction, maximizing the failure coefficients of all piers and spandrel beams (Cp, Cs) and of piers shear strength (If) in an entire plane. This does not consider that the value of the minimum safety index Is could be due to a specific weakness located in the construction rather than to a general stiffness lack.

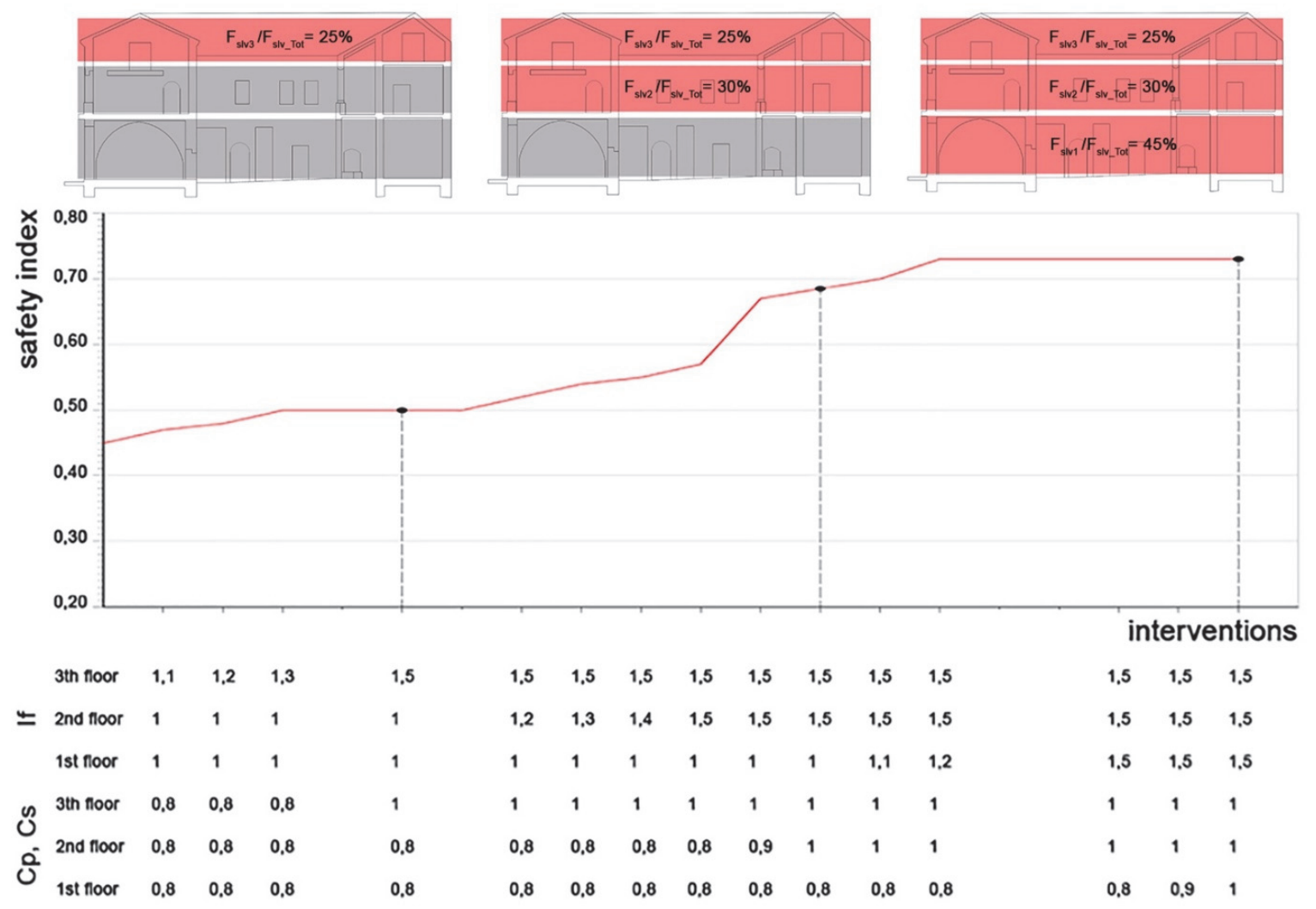

Figure 10: Safety index curve of "Palazzo Petrucci Novelli". 
On the contrary it is possible to minimize interventions and consequent costs gradually increasing the shear strength and the specific failure coefficients (where necessary). Essentially with a view to achieving the same improvement result but optimizing choices and costs.

Following the latter approach (hypothesis of targeted and optimized interventions), the maximum increase in the minimum safety index is obtained by increasing the shear strength by $50 \%$ at the third and second floors and only $20 \%$ on the first floor. The failure coefficients of piers and spandrel beams (assumed equal in both the $\mathrm{x}$ and $\mathrm{y}$ directions) are increased up to the unity for the third and second floor while they remained unchanged at the first floor.

By maximizing all the values of shear strength (If $=1.5)$ and failure coefficients $(\mathrm{Cp}=\mathrm{Cs}=1)$ at every level of the constructions, the safety index curve rises rapidly to reach the same value of 0.73 . In such a case, there would therefore be a waste in terms of costs, uselessly strengthening the first floor too, where instead it is sufficient to increase by only $20 \%$ the pier shear strength without changing the failure modes of piers and spandrels.

The aforementioned analyses highlight that both design choices allow to improve the seismic capacity of the building, increasing the minimum safety index Is from 0.45 to 0.73 . However, in the case of optimized interventions, the strengthening would be lower, less expensive and really located on the structural parts affected by structural deficiencies, while in the other case (widespread interventions) there would be unjustifiable and expensive interventions at a global level on the whole building.

\section{"Palazzo Ducale"}

In this case, as pointed out in Fig. 11, the building analysis returns an initial safety index of 0.25 , which being lower than 1 shows a significant incapability to cope with a seismic event, a more critical condition than the previously studied case. Also, for this second building, a double analysis is carried out based on two different design choices: the first with a gradual increase in resistance and failure coefficients and a second one based on the simultaneous maximization of all increases.

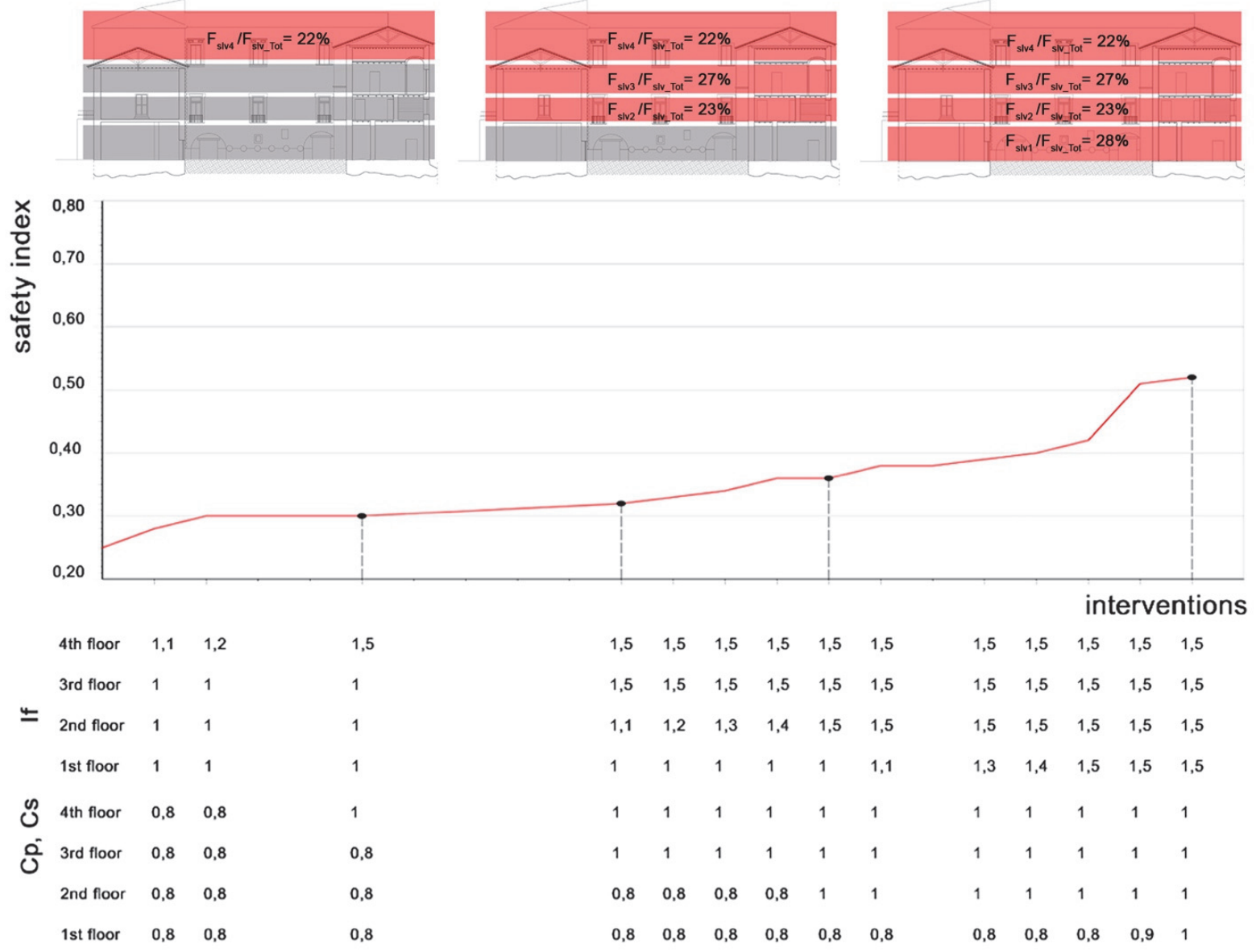

Figure 11: Safety index curve of "Palazzo Ducale". 
Also, in this case the weakest level is the fourth floor in which there is just the $22 \%$ of the shear strength of the entire construction.

Unlike the previous case, for this type of building, the maximum increase in the safety index (and the related structural improvement) is obtained, for both design approaches, by maximizing both the pier shear strength (If) at all stories in both directions and the failure coefficients of piers and spandrel (Cp, Cs).

This is clearly shown in Fig. 11, where the curve representing the gradual increase of the safety index from 0.25 (initial scenario) to 0.52 is obtained by increasing the shear strength by $50 \%$ to all levels and assuming a unitary value for all the collapse coefficients $\mathrm{Cp}$ and $\mathrm{Cs}$ (assumed equal in both the $\mathrm{x}$ and $\mathrm{y}$ direction).

The black points, representative of widespread interventions on the entire building, confirm that in this case the real improvement of the seismic capacity requires a global strengthening intervention on the entire building structure.

This type of simplified method is able to identify the weak level of any structure, succeeding in this way to optimize the interventions and to localize them on the weak parts. The interventions aim to increase the compressive and shear strength. Several types of intervention are possible for cultural masonry heritage.

There are many strengthening configurations, different in technique and material that achieve the same result and whose geometrical details are difficult to establish in advance. The improvement of the building seismic performances may be achieved using traditional fiber-reinforced composites systems (FRP), suitable as structural reinforcing elements.

\section{CONCLUSIONS}

7 his paper deals with some issues concerning the vulnerability assessment of masonry buildings and the optimization of the strengthening interventions to be adopted. The case studies are two stone masonry buildings in the area of Caserta, Southern Italy.

Particular attention is paid to simplified assessment methods that require a less thorough knowledge of the structure, leading to results that can be sufficiently reliable. They are of fast application and are particularly suitable for the analysis of large and complex buildings, especially when they are placed in historic centers.

The simplified method illustrated allows an optimization of strengthening and has been applied to two buildings representative of a wide number of residential buildings in Caserta: a building in the historic center of Carinola, an area with medium-low seismic hazard, representative of regular buildings made of simple stone, and a second building built in the historic center of Piedimonte Matese, an area of high seismic hazard, highly irregular in its configuration and made with mixed materials of various types. The seismic vulnerability has been assessed using a quantitative method, based on the procedure provided by the Italian guidelines for the assessment and mitigation of seismic risk of cultural heritage. For the first examined building ("Palazzo Petrucci-Novelli"), the analyses show an average vulnerability. In this case the seismic capacity of the building can be improved optimizing the strengthening interventions. In this case, in fact, the adopted iterative procedure allows concentrating interventions only on the structural elements characterized by structural deficiencies, avoiding widespread unnecessary interventions throughout the building (that would not lead to a larger increase in the safety index), and which would therefore be economically unjustifiable. The results obtained for the second building ("Palazzo Ducale") show a high vulnerability. In this case the iterative procedure leads to the same results in terms of increasing the minimum safety index achieved by assuming widespread interventions throughout the building.

\section{REFERENCES}

[1] De Matteis G., Brando G., Corlito V., Criber E., Guadagnuolo M. (2019). "Seismic vulnerability assessment of churches at regional scale after the 2009 L'Aquila earthquake", Int. J. Masonry Research and Innovation, 4(1-2), pp.174-196.

[2] Bergamasco, I., Gesualdo, A., Iannuzzo, A., Monaco, M. (2018). An integrated approach to the conservation of the roofing structures in the Pompeian domus, J. Cult. Herit., 31, pp. 141-151. DOI:10.1016/j.culher.2017.12.006.

[3] Cattari, S., Degli Abbati, D., Ferretti, D., Lagormarsino, S., Ottonelli, D., Rossi, M., et al. (2012). The seismic behaviour of ancient masonry buildings after the earthquake in Emilia (Italy) on May 20th and 29th, Ing Sismica., Anno XXIX(2-3)., pp. 87-111.

[4] Masi, A., Santarsiero, G., Ventura, G. (2017). Strategie per la riduzione del rischio sismico applicate agli edifici scolastici: un caso studio., Anidis 2017 Pistoia., pp. 2232 - 2240. 
[5] Costantine, C., Spyrakos. (2018). Bridging performance based seismic design with restricted interventions on cultural heritage structures. Engineering Structures., pp. 160:34-43.

[6] Bosiljkov, V., Uranjek, M., Zarnìc, R., Bokan-Bosiljkov, V. (2010). An integrated diagnostic approach for the assessment of historic masonry structures, Journal of Cultural Heritage 11, pp. 239-249. DOI: 10.1016/j.culher.2011.11.007.

[7] Ceroni, F., Pecce, M., Manfredi, G. (2009). Seismic Assessment of the Bell Tower of Santa Maria Del Carmine: Problems and Solutions, Journal of Earthquake Engineering, pp. 14:1, 30-56. DOI: 10.1080/13632460902988968.

[8] Milani, G., Shehu, R., Valente, M. (2017). Seismic Assessment of Masonry Tower by Means of Nonlinear Static Procedures, $X$ International Conference on Strctural Dynamics, EURODYN.

[9] Guadagnuolo, M., Faella, G., Donadio, A., Ferri, L. (2014). Integrated evaluation of the Church of S. Nicola di Mira: Conservation versus safety. NDT \& E International., Elsevier., pp. 68, 53-65.

[10] Giovinazzi, S., Lagomarsino, S. (2004). A macroseismic models for the vulnerability assessment of the buildings, 13th World Conference on Earthquake. 896.

[11] Zuccaro, G., Cacace, F. (2009). Modello per la simulazione di scenari sismici per la Regione Campania., L'Ingegneria Sismica in Italia. Bologna, Italy.

[12] Guadagnuolo, M., Nuzzo, M., Faella, G. (2018). The Corpus Domini Bell Tower: Conservation and Safetys., XIV International Conference on Bulding Pathology and Construction Repair - CINPAR., 11, pp. 444-451. DOI: $10.1016 /$ j.prostr.2018.11.057

[13] Dolce, M., Di Pasquale, G., Speranza E. (2012). A multipurpose method for seismic vulnerability assessment of urban areas., 15 WCEE LISBOA 2012.

[14] Direttiva del Presidente del Consiglio dei Ministri 9 Febbraio 2011; riferimento NTC D.M. 14.01.08 - Valutazione e riduzione del rischio sismico del patrimonio culturale.

[15] Guadagnuolo, M., Aurilio, M., Faella, G. (2017). Rischio sismico di edifici in muratura: metodi a confronto., Anidis 2017 Pistoia. pp. $2171-2180$.

[16] Monaco, M., Bergamasco, I, Betti, M. (2018). A no-tension analysis for a brick masonry vault with lunette, Journal of Mechanics of Materials and Structures, 13(5), pp. 703-714, DOI: 10.2140/jomms.2018.13.703.

[17] Guadagnuolo M., Monaco, M. (2009). Out of plane behaviour of unreinforced masonry walls. In: Protection of Historical Buildings, 2, pp. 1177-1180, London, New York: CRC Press, Taylor \& Francis Group.

[18] De Matteis G., Corlito V., Criber E., Guadagnuolo M., 2016. Evaluation of earthquake damage scenario of churches at regional scale_Experiences in Abruzzi and perspectives in Campania, Proceedings of theXIV Forum Internazionale di Studi "Le Vie dei Mercanti" - WORLD HERITAGE and DEGRADATION Smart Design, Planning and Technologies, Napoli-Capri, Italy.

[19] Cimino, G., Ricci, I., Gasparini, G., Trombetti, T. (2017). Seismic vulnerability of building heritage of the University of Bologna: methodology and analysis., 16th World Conference on Earthquake, 16WCEE 2017 Santiago Chile.

[20] Caterino, N., Cosenza E. (2017). Evalution of seismic retrofit techniques via a multicriteria approach accounting for Italian tax incentives. Anidis 2017 Pistoia. pp. $2181-2190$.

[21] Petrucci, E. (2017). Considerazioni sulle procedure attuate dopo il siam del 1997 nella Regione Marche: nuovi contributi al consolidamento delle opere murarie., Anidis 2017 Pistoia. pp. 2386 - 2396.

[22] Guadagnuolo, M., Paolillo, A. (2012). Territorial seismic safety evaluation and appropriate survey: liberty buildings in Naples. Proceedings of theX Forum Internazionale di Studi "Le Vie dei Mercanti" - Less More architecture, design, landscape, Aversa-Capri, Italy.

[23] De Matteis G., Corlito V., Guadagnuolo M. and Tafuro A. (2019). Seismic Vulnerability Assessment and Retrofitting Strategies of Italian Masonry Churches of the Alife-Caiazzo Diocese in Caserta, Int. J. Architectural Heritage, DOI: $10.1080 / 15583058.2019 .1594450$.

[24] Corlito V., Guadagnuolo M., Tafuro A., De Matteis G., 2017. Seismic risk assessment of one nave complex churches. The Alife-Caiazzo diocese in Caserta province, Proc. 3rd International Conference on Protection of historical constructions, Lisbon.

[25] Faella G., Guadagnuolo M., 2007. La sicurezza sismica degli opifici mediterranei in muratura, Proceedings of theV Forum Internazionale di Studi "Le Vie dei Mercanti” - Rappresentare il Mediterraneo, Capri, Italy.

[26] Guadagnuolo M., Nuzzo M., Faella G., "eismic Safety of the "Corpus Domini” Bell Tower, Proceedings XII Forum Internazionale di Studi "Le Vie dei Mercanti" - Best pratice in Heritage, Conservation, Management from the world to Pompeii, Aversa-Capri, Italy.

[27] MIT, 2008. Norme Tecniche per le Costruzioni, D.M. 14/01/2008, Official Bulletin n. 29, 04.02.2008. 
[28] MIT, 2018. Norme Tecniche per le Costruzioni, D.M. 17/01/2018, Official Bulletin n. 42, 20.02.2018.

[29] Bartoli, G., Betti, M., Galano, L., Zini, G. (2019). Numerical insights on the seismic risk of confined masonry towers. Engineering Structures, (180) pp. $713-727$.

[30] Formisano, A., Marzo, A. (2018). Simplified and refined methods for seismic vulnerability assessment and retrofitting of an Italian cultural heritage masonry building. Computers and Structures., pp. 13 - 26.

[31] Ademovi’N., Oliveira D.V., Lourenço P.B., Seismic Evaluation and Strengthening of an Existing Masonry Building in Sarajevo, B\&H, Buildings 2019, 9, 30; DOI:10.3390/buildings9020030.

[32] Betti, M., Galano, L., Petracchi, M. and Vignoli, A. (2015). Diagonal cracking shear strength of unreinforced masonry panels: a correction proposal of the b shape factor, B. Earthq. Eng., 13(10), pp. 3151-3186. DOI: $10.1007 /$ s10518-015-9756-8.

[33] Betti, M., Galano, L., Vignoli, A. (2008). Seismic response of masonry plane walls: A numerical study on spandrel strength, AIP Conf. Proc., 1020(1), pp. 787-794. DOI: 10.1063/1.2963915.

[34] Monaco, M., Calderoni, B., Iannuzzo, A., Gesualdo, A. (2018). Behaviour of in-plane loaded masonry panels, Procedia Struct. Integrity, 11, pp. 388-393. DOI: 10.1016/j.prostr.2018.11.050. 